\title{
Irrigation Schedule with Different Nitrogen Sources and Levels for Maize Productivity and Some Water Relations
}

\author{
A. M. Abd El-Hafeez ${ }^{1}$, and Samah O. Bashandy ${ }^{2 *}$ \\ ${ }^{1}$ Soil and Water Sci. Dep., Fac., of Agric., Beni-Suef University, Egypt \\ ${ }^{2}$ Soil and Water Sci. Dep., Fac., of Agric., Minia University, Egypt
}

\begin{abstract}
$\mathbf{T}$ WO FIELD experiments were conducted in two successive summer seasons during 2016 and 2017 at Sids Agricultural Research Station, Beni-Suef Governorate, Egypt. This research was carried out to study irrigation schedule impact using pan evaporation method (Class A pan and irrigation at $0.7,1.0$ and 1.3 pan evaporation coefficient, APE) with different nitrogen sources (ammonia gas, ammonium nitrate and urea) and levels (214 and $286 \mathrm{~kg} \mathrm{~N} \mathrm{ha}^{-1}$ ) on maize yield attributes as well as some water relations, namely, seasonal applied water (AP), seasonal consumptive use (CU), water utilization efficiency (WUtE) and water use efficiency (WUE). Results showed that increasing pan evaporation coefficient from 0.7 up to 1.3 increased maize yield and improved its attributes, N, P and K uptake by grains and/or stover, seasonal applied water and seasonal consumptive use. The differences between the effect of 1.0 and 1.3 of APE on maize grain and stover yields were not significant. Irrigation at 1.0 APE gave the highest WUtE and WUE followed by irrigation at 1.3 APE. Whereas the lowest one produced under 0.7 of APE Added nitrogen as anhydrous ammonia increased all studied yield and its attributes, N, P and K uptake, seasonal consumptive use, water utilization efficiency and water use efficiency followed by ammonium nitrate, while urea fertilizer exhibited the lowest ones. Increasing nitrogen levels from 214 to $286 \mathrm{Kg} \mathrm{ha}^{-1}$ improved maize yield and its attributes, N, P and $\mathrm{K}$ uptake as well as the studied water relations. The best treatment for maize productivity and water relation is to irrigate at 1.0 of APE with nitrogen addition as ammonia gas at the rate of $286 \mathrm{Kg} \mathrm{ha}^{-1}$, while saving about $960 \mathrm{~m}^{3}$ per hectare with no significant decrease in yield. This study confirms that maize irrigation at different pan evaporation coefficient $(0.7,1.0$ and 1.3$)$ with different nitrogen fertilization sources and levels affect maize productivity traits and some water relations.
\end{abstract}

Keywords: Maize attributes, Nitrogen sources and nitrogen levels, Pan coefficient, Water relations.

\section{Introduction}

Water is the most limiting natural resource for agricultural production in arid and semi-arid regions. Nowadays the total annual water resource of Egypt is about 67.27 billon $\mathrm{m}^{3}$ (Hafiz and Ewis, 2015). The agricultural sector consumes almost $80-90 \%$ of the total water allocated to Egypt. Therefore, there is a need for decreasing plant water consumption through using more efficient irrigation methods (Tayel et al., 2007), plant breeding technology, longer irrigation intervals, higher moisture depletion, skipping during the early vegetative growth or during maturation stage, and timing length of irrigation interval with the stage of plant growth (Faki, 1991). Moreover,
Egypt is the 15th most populated country in the world. Its population has tripled during the last 50 years. Egypt receives about 98 per cent of its fresh water from the Nile River originating outside its international border (Zorkany, 2014). The usefulness of evaporation pan to predict soil moisture deficit in field and to estimate the crop water requirement for weekly and long period is discussed in detail by Ashraf et al. (2002), Khalil and Mohamed (2006) and Eid et al. (2010). El bably (2007) stated that irrigation scheduling of maize at 1.2 of accumulation of pan evaporation significantly increased plant height, ear length, number of rows/ears, number of grains/rows, 100 -grain weight and grain yield. 
Nitrogen is an essential nutrient for both maize quantity and quality as it is a component of protein and chlorophyll. It is thus, essential for photosynthesis, vegetative and reproductive growth and it often determines yield of maize (Igbal et al., 2006). Nitrogen for maize cultivation is equally important to realize the yield potential (Sajedi et al., 2009). Among different elements of Egypt soil, nitrogen is the key input for achieving higher yield of maize, but nitrogenous fertilizer may be increased to a certain level and thereafter it has got adverse effect. It was generally observed that maize fail to produce good grains in plots without adequate nutrients. Therefore, the supply of nitrogen is important for maize production as much as water. On the other hand, indiscriminate use of nitrogen leads to increase in production costs and environmental contamination (Gurpreet et al., 2013). Inorganic nitrogen fertilizer exerts strong influence on plant growth, development and yield (Stefano et al., 2004). The availability of sufficient nutrients from inorganic fertilizers lead to improve all activities, enhanced cell multiplication and enlargement and luxuriant growth (Fashina et al., 2002). Luxuriant growth resulting from nitrogen fertilizer application leads to larger dry matter production (Obi et al., 2005), owing better utilization of solar radiation and many investigators stated that increasing nitrogen levels were increased growth, yield and its components, and nutrient uptake of maize (Ismail et al., 1999; Ismail et al., 2006; Sadik et al., 2009; Ali et al., 2012; Abd El-Hafeez et al., 2013, and Wang and Xing, 2017). In general, increases in soil moisture promote the response of maize yield to nitrogen application, especially al high nitrogen rate (Eck, 1984). Also, N uptake was strongly affected by water supply (Martin et al., 1982). Norwood (2000) and El-Sharkawy et al. (2006) pointed out that increasing $\mathrm{N}$ rate was accompanied with markedly increase in maize grain yield under applied adequate water. In this concern, Eid et al. (2010); Azizian and Sepaskhah (2014), and Nilahyana et al. (2018) show that nitrogen use efficiency (NUE) increased with decreasing water applied and decreased with increasing $\mathrm{N}$ rate.

Maize is one of the most important crops in the world. It is the third major cereal crop after wheat and rice with regard to the world production. However, it is the highest yielding cereal crop known. It is a major feed crop in many countries, because the grains are rich in the energy and its use in the manufacture of many industrial products. Keeping in view, the above said points, field experiments were conducted to examine the interaction irrigation at different pan evaporation coefficient $(0.7,1.0$ and 1.3$)$, sources and levels of nitrogen fertilizers on maize productivity and some water relations.

Egypt. J. Soil. Sci. 59, No. 1 (2019)

\section{Materials and Methods}

The present research trials were conducted during 2016 and 2017 summer seasons at the experimental Farm of Sids Agricultural Research Station, Beni-Suef Governorate, Middle Egypt, Lat. $29^{\circ} 04 \mathrm{~N}$, long $31^{\circ} 06 \mathrm{E}$ and $30-40 \mathrm{~m}$ above the mean sea level. Some physico-chemical properties and soil moisture constants of the experimental sites were determined and listed in Tables 1 and 2 (according to Klute, 1986 and Page et al. 1982). Some metrological data of the experimental site which were recorded during two growth seasons of maize plants are illustrated in Table 3. The experimental design was split-split plot design in three factors with four replicates. The factors were:

1- Irrigation scheduling treatments which carried out using the pan evaporation method (Class A pan), the treatments were irrigation at $1.3\left(\mathrm{I}_{1}\right)$, $1.0\left(\mathrm{I}_{2}\right)$ and $0.7\left(\mathrm{I}_{3}\right)$ pan evaporation coefficient.

2- Nitrogen sources, namely, urea $(46.5 \% \mathrm{~N}$, $\mathrm{U})$, ammonium nitrate $(33.5 \% \mathrm{~N}, \mathrm{AN})$ and ammonia gas $(82 \% \mathrm{~N}, \mathrm{AG})$.

3- Nitrogen levels at rate of 214 and $286 \mathrm{~N} \mathrm{ha}^{-1}$.

The irrigation treatments were allocated in main plots and the nitrogen sources were devoted in sub plot, while nitrogen levels were randomly assigned in sub-sub plots. Urea and ammonium nitrate fertilizers were added at two equal doses before first and second irrigations, while ammonia gas treatments were injected directly into soil (at $14 \%$ moisture) at $15 \mathrm{~cm}$ depth, $30 \mathrm{~cm}$ spacing between points of injection before 7 days from sowing. Grains of maize (Zea mays L.) cultivar Single cross 10 were sown in 15th and 20th June in the two seasons, respectively, the experimental plot consisted of five ridges, 4.2 meters in length and $60 \mathrm{~cm}$ apart, occupying an area of $12.6 \mathrm{~m} 2$ (about 1/794 hectare). The phosphorus fertilizer was added to all plots as calcium superphosphate $(15.5 \% \mathrm{P} 2 \mathrm{O} 5)$ at rate of $55 \mathrm{~kg} \mathrm{P} 2 \mathrm{O} 5 /$ ha before sowing, while potassium fertilizer was applied as potassium sulphate $(48 \% \mathrm{~K} 2 \mathrm{O})$ at rate of $57 \mathrm{~kg}$ $\mathrm{K} 2 \mathrm{O} /$ ha in two equal doses, the first after thinning and the second at one month later. Wheat is the preceding crop. All other agricultural practices were applied as done in the region.

At harvesting ten plants were chosen randomly from the inner rows of each plot to measured maize yield components, i.e., number of rows ear ${ }^{1}$, number of grains row ${ }^{-1}$ and 100 grain weight. Also, grain and stover yields were determined for each plot and converted to $\mathrm{tha}^{-1}$. Representative samples were taken from grains and stover to determine $\mathrm{N}, \mathrm{P}$ and $\mathrm{K}$ concentrations according to AOAC (1990), Then N, P and K uptake in grains and/or stover were calculated. 
TABLE 1. Some soil physicochemical properties of the experimental site in 2016 and 2017 seasons

\begin{tabular}{|c|c|c|c|c|c|c|}
\hline \multicolumn{3}{|c|}{ Soil properties } & 2016 & 2017 & & \\
\hline \multicolumn{7}{|c|}{ Soil particle distribution: } \\
\hline \multicolumn{7}{|c|}{ Particle size distribution: } \\
\hline \multicolumn{3}{|c|}{ Clay $(\%)$} & 51.11 & & \multicolumn{2}{|l|}{50.35} \\
\hline \multicolumn{3}{|l|}{ Silt (\%) } & 32.36 & & \multicolumn{2}{|l|}{31.67} \\
\hline \multicolumn{3}{|l|}{ Sand $(\%)$} & 16.53 & & \multicolumn{2}{|l|}{17.98} \\
\hline \multicolumn{3}{|c|}{ Texture grade } & Clay & & \multicolumn{2}{|l|}{ Clay } \\
\hline \multicolumn{7}{|c|}{ Chemical properties: } \\
\hline \multicolumn{3}{|c|}{ pH (1:2.5 soil-water suspension) } & \multicolumn{2}{|l|}{7.95} & \multicolumn{2}{|l|}{8.00} \\
\hline \multicolumn{3}{|c|}{ EC, soil paste $\left(\mathrm{dS} \mathrm{m}^{-1}\right)$} & \multicolumn{2}{|l|}{1.13} & \multicolumn{2}{|l|}{1.23} \\
\hline \multicolumn{3}{|c|}{ Organic matter $(\%)$} & \multicolumn{2}{|l|}{1.61} & \multicolumn{2}{|l|}{1.75} \\
\hline \multicolumn{3}{|c|}{ Available N (mg kg) } & \multicolumn{2}{|l|}{22.50} & \multicolumn{2}{|l|}{23.72} \\
\hline \multicolumn{3}{|c|}{ Available P (mg kg) } & \multicolumn{2}{|l|}{15.1} & \multicolumn{2}{|l|}{17.3} \\
\hline \multicolumn{3}{|c|}{ Available K (mg kg) } & \multicolumn{2}{|l|}{187} & \multicolumn{2}{|l|}{179} \\
\hline Season & $\begin{array}{c}\text { Soil depth } \\
(\mathrm{cm})\end{array}$ & $\begin{array}{c}\text { Field Capacity } \\
(\% \mathrm{w} / \mathrm{w})\end{array}$ & $\begin{array}{c}\text { Wilting Point } \\
(\% \mathrm{w} / \mathrm{w})\end{array}$ & $\begin{array}{c}\text { Bulk Density } \\
\left(\mathrm{g} \mathrm{cm}^{-3}\right)\end{array}$ & $\begin{array}{r}\text { Ava } \\
\text { W } \\
(\mathbf{w} / \mathrm{v}\end{array}$ & $\begin{array}{l}\text { able } \\
\text { ter } \\
\% \text { ) }\end{array}$ \\
\hline & & & & & $\mathrm{W} \%$ & $\mathrm{~mm}$ \\
\hline & $0.0-15$ & 46.09 & 22.36 & 1.162 & 23.73 & 41.36 \\
\hline 2016 & $15-30$ & 35.91 & 16.15 & 1.172 & 19.76 & 34.74 \\
\hline & $30-45$ & 33.78 & 15.33 & 1.176 & 18.45 & 32.54 \\
\hline & $45-60$ & 31.30 & 14.92 & 1.181 & 16.35 & 27.74 \\
\hline & $0.0-15$ & 46.31 & 23.35 & 1.179 & 22.96 & 40.60 \\
\hline 2017 & $15-30$ & 38.15 & 18.97 & 1.253 & 19.18 & 36.05 \\
\hline 2011 & $30-45$ & 35.19 & 17.52 & 1.266 & 17.67 & 33.56 \\
\hline & $45-60$ & 32.51 & 16.16 & 1.315 & 16.36 & 32.27 \\
\hline
\end{tabular}

TABLE 3. Some metrological data of the experimental site during both growth seasons of maize plants

\begin{tabular}{|c|c|c|c|c|c|c|c|c|c|c|}
\hline \multirow{3}{*}{$\begin{array}{l}\text { Seasons } \\
\text { Intervals }\end{array}$} & \multicolumn{5}{|c|}{2016} & \multicolumn{5}{|c|}{2017} \\
\hline & \multicolumn{2}{|c|}{$\begin{array}{c}\text { Air temperature } \\
\text { C }\end{array}$} & \multicolumn{2}{|c|}{$\begin{array}{c}\text { Relative } \\
\text { humidity\% }\end{array}$} & \multirow{2}{*}{$\begin{array}{c}\text { E.P } \\
\mathrm{mm} / \\
\text { day }\end{array}$} & \multicolumn{2}{|c|}{$\begin{array}{c}\text { Air } \\
\text { temperature C }\end{array}$} & \multicolumn{2}{|c|}{$\begin{array}{c}\text { Relative } \\
\text { humidity\% }\end{array}$} & \multirow[t]{2}{*}{$\begin{array}{c}\text { E.P mm } \\
\text { day }\end{array}$} \\
\hline & Max. & Min. & Max. & Man. & & Max. & Min. & Max. & Min. & \\
\hline $01-10 / 6$ & 33.8 & 21.1 & 88 & 21 & 7.8 & 34.1 & 20.4 & 75 & 22 & 8.0 \\
\hline $11-20 / 6$ & 35.7 & 21.8 & 88 & 22 & 8.0 & 34.8 & 20.5 & 78 & 23 & 8.1 \\
\hline $21-30 / 6$ & 37.3 & 22.0 & 87 & 22 & 8.1 & 35.2 & 21.6 & 79 & 24 & 8.3 \\
\hline $01-10 / 7$ & 40.7 & 24.2 & 86 & 23 & 8.3 & 38.8 & 24.5 & 74 & 25 & 8.4 \\
\hline $11-20 / 7$ & 41.2 & 25.7 & 87 & 24 & 8.5 & 40.9 & 26.3 & 75 & 27 & 8.6 \\
\hline $21-31 / 7$ & 43.1 & 26.3 & 87 & 25 & 8.7 & 42.1 & 26.9 & 76 & 27 & 8.7 \\
\hline $01-10 / 8$ & 42.5 & 24.9 & 86 & 26 & 8.6 & 41.6 & 25.2 & 75 & 26 & 8.5 \\
\hline $11-20 / 8$ & 41.1 & 24.4 & 86 & 29 & 8.4 & 40.0 & 24.8 & 74 & 26 & 8.3 \\
\hline $21-31 / 8$ & 40.9 & 24.0 & 87 & 29 & 8.3 & 39.6 & 24.0 & 77 & 24 & 8.0 \\
\hline $01-10 / 9$ & 39.1 & 23.3 & 82 & 27 & 7.5 & 38.5 & 23.8 & 81 & 20 & 7.5 \\
\hline $11-20 / 9$ & 37.2 & 22.9 & 80 & 27 & 7.3 & 37.3 & 22.7 & 79 & 21 & 7.3 \\
\hline $21-30 / 9$ & 34.3 & 21.1 & 80 & 25 & 7.2 & 37.0 & 21.8 & 79 & 22 & 7.1 \\
\hline 01-10/10 & 33.5 & 19.9 & 76 & 21 & 6.0 & 33.2 & 19.8 & 70 & 22 & 6.5 \\
\hline $11-20 / 10$ & 31.6 & 19.3 & 77 & 19 & 5.8 & 30.6 & 19.1 & 71 & 21 & 6.3 \\
\hline $21-31 / 10$ & 30.1 & 18.7 & 78 & 18 & 5.6 & 32.3 & 18.6 & 75 & 24 & 6.0 \\
\hline
\end{tabular}


Soil and water relationships measurements and calculations

-Time of irrigation

The available water has been converted to water depth in $\mathrm{mm}$ as shown in Table (2), it was 136.38 and $142.48 \mathrm{~mm}$ for both growth seasons, respectively. At every irrigation event, the equivalent amount of evaporation that can occur was estimated, meanwhile amount of available soil water is being used. Scheduling of irrigation started after applying the first irrigation. Monthly accumulative pan evaporation (APE), number and irrigation intervals are given in Table (4).

-Irrigation water applied (WA)

Irrigation water was calculated by the summation of the daily records of class A pan evaporation.
Seasonal applied irrigation water

Submerged flow orifice with fixed dimension was used to measure the amount of water applied according to Michael, 1978 as the following equation.

$Q=C A \sqrt{2 g h}$

where:

$\mathrm{Q}=$ discharge through orifice ( $\mathrm{L} / \mathrm{sec}$.).

$\mathrm{C}=$ coefficient of the discharge (0.61).

$\mathrm{A}=$ cross-section area of orifice $\left(\mathrm{cm}^{2}\right)$.

$\mathrm{g}=$ acceleration of gravity $(980 \mathrm{~cm} / \mathrm{sec} 2)$.

$\mathrm{h}=$ pressure lead causing discharge through the orifice $(\mathrm{cm})$.

TABLE 4. Accumulative pan evaporation (APE) number and irrigation intervals during both growing seasons

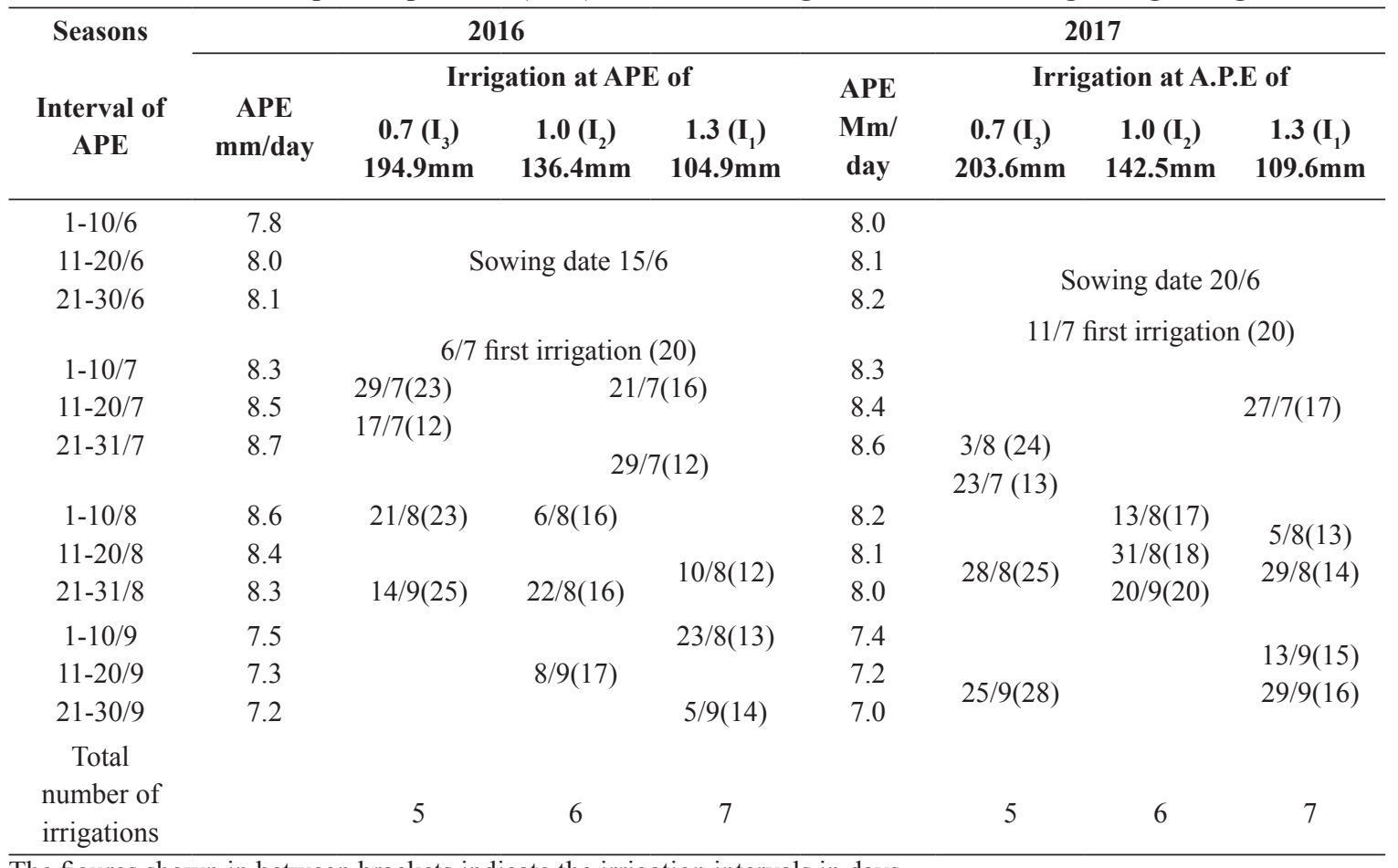

The figures shown in between brackets indicate the irrigation intervals in days.

TABLE 4a. Seasonal water applied (m3 ha-1) as affected by irrigation treatments for both seasons

\begin{tabular}{|c|c|c|c|c|c|c|}
\hline \multirow[b]{2}{*}{ No of irrigation } & \multicolumn{6}{|c|}{ Irrigation treatments } \\
\hline & \multicolumn{2}{|c|}{ 1.3 APE (I1) } & \multicolumn{2}{|c|}{ 1.0 APE (I2) } & \multicolumn{2}{|c|}{0.7 APE (I3) } \\
\hline Sowing irrigation & 1326 & 1308 & 1326 & 1308 & 1326 & 1308 \\
\hline Fourth irrigation & 1139 & 1081 & 1136 & 1107 & 1465 & 1349 \\
\hline Fifth irrigation & 1164 & 1128 & 1241 & 1207 & 1229 & 1218 \\
\hline Sixth irrigation & 1124 & 1104 & 1160 & 1135 & ----- & ----- \\
\hline Seventh irrigation & 1106 & 1038 & ----- & ----- & ----- & ----- \\
\hline
\end{tabular}

Egypt. J. Soil. Sci. 59, No. 1 (2019) 
TABLE 4b. Number and irrigation intervals as affected by irrigation treatments

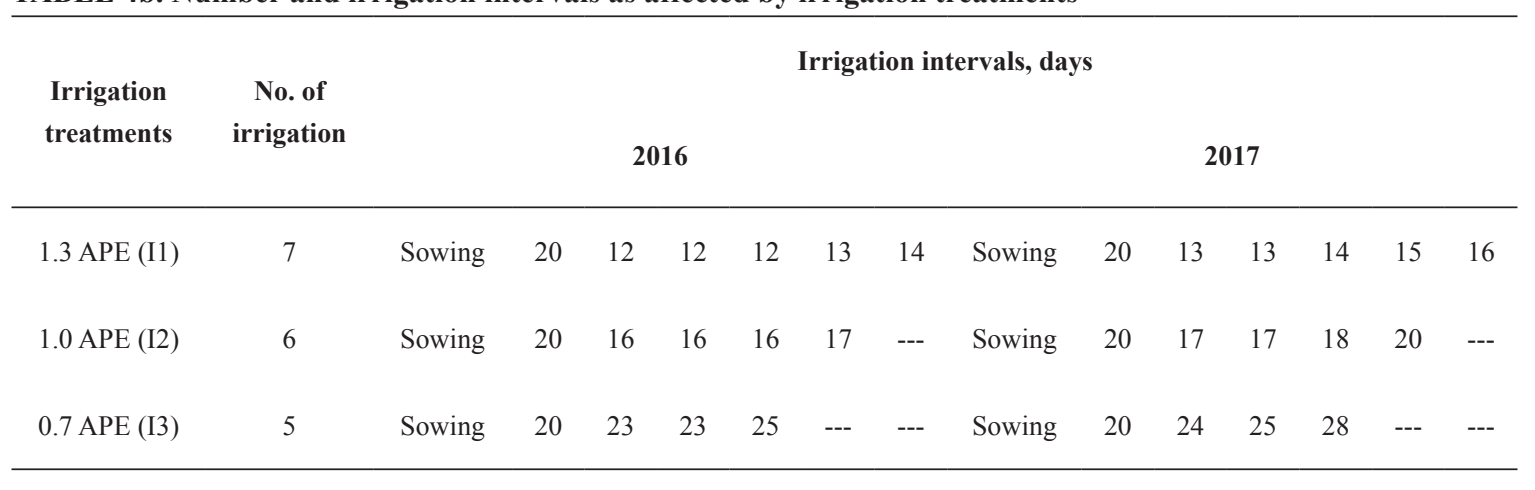

Crop - water relation parameters

- Seasonal consumptive use (CU)

To determining the crop water consumptive use, soil samples were taken just before irrigation, 48 hours after each irrigation event and at harvest in $15 \mathrm{~cm}$ increment system to $60 \mathrm{~cm}$ depth of the soil profile. The crop water consumptive use between each two successive irrigation was calculated according to Israelsen and Hansen (1962) as follow:

$$
\mathrm{CU}=\frac{\mathrm{D} \cdot \mathrm{Bd}\left(\mathrm{Q}_{2}-\mathrm{Q} 1\right)}{100}
$$

where:

$\mathrm{CU}=$ Actual consumptive use $(\mathrm{cm})$.

$\mathrm{D}=$ Effective root zone depth $(\mathrm{cm}), 60 \mathrm{~cm}$.

$\mathrm{Bd}=$ Bulk density of depth $(\mathrm{g} / \mathrm{cm}-3)$.

$\mathrm{Q}_{2}=$ Soil moisture percentage (wt/wt) two days after irrigation.

$\mathrm{Q}_{1}=$ Soil moisture percentage (wt/wt) just before the next irrigation.

The time need for each plot was recorded.

- Water use efficiency (WUE)

The water use efficiency as water consumed per $\mathrm{kg}$ seed maize $/ \mathrm{m}^{3}$ was calculated for each treatment following the formula described by Vites (1965).

$$
\begin{aligned}
& \text { WUE }\left(\mathrm{kg} / \mathrm{m}^{3}\right)=\frac{\text { Maize grain yield }\left(\mathrm{kg} \mathrm{ha}^{-1}\right)}{\text { Consumptive use }\left(\mathrm{m}^{3} \mathrm{ha}^{-1}\right)} \\
& \text { - Water utilization efficiency (Water productivity, } \\
& \text { WP) }
\end{aligned}
$$

Water productivity is an efficiency term calculated as a ratio of product water output over water input. Water productivity in the present study is expressed as kilogram of maize grain yield per unit of applied irrigation water (FAO, 2003).

$$
\mathrm{WP}=\left(\mathrm{kg} / \mathrm{m}^{3}\right)=\frac{\text { Maize grain yield }\left(\mathrm{kg} \mathrm{ha}^{-1}\right)}{\text { Water applied }\left(\mathrm{m}^{3} \mathrm{ha}^{-1}\right)}
$$

\section{Statistical analysis}

The obtained data were statistically analyzed by analysis of variance according to method described by Snedecor and Cochran (1980). Duncan's multiple range for comparing the differences between treatment means was used at the probability level of 0.05 .

\section{Results and Discussion}

\section{Yield components}

Data in Table 5 represent the effect of irrigation scheduling, nitrogen sources and levels on yield components of maize. The data indicated that irrigation at $1.3\left(\mathrm{I}_{1}\right)$ accumulative evaporation (APE) gave statistically number of rows/ear, number of grains/row and 100-grain weight equal to those under $\mathrm{I}_{2}$ and higher than $\mathrm{I}_{3}$. The reduction of these parameters resulted to decrease moisture content $\left(\mathrm{I}_{3}\right)$ reached to $2.7,6.2$ and $14.6 \% \operatorname{over}\left(\mathrm{I}_{2}\right)$, respectively in the first season. The corresponding decreasing in the second season were 2.4, 6.1 and $14.5 \%$ in the same order. It is obvious to notice that effect of the reduction of moisture content was more pronounced in the weight of grains than the other two yield component parameters. These reductions in yield component parameters may be due to water shortage that causes the close of the stomata and reduce all metabolism process within plant tissues (Eid et al., 2010). Also, Kuchenbuch et al. (2006) and Sangakkara et al. (2010) mentioned that, the lack of sufficient soil moisture affects growth and development of roots. Similar results were obtained by Galbiatti et al. (2004) and El-Tantawy et al. (2007) who reported that yield components of maize plants were gradually increased as a result of increasing soil moisture content. 
As for different nitrogen sources, the data reveal that all studied maize yield components were significantly affected by nitrogen fertilizer sources. It could be arranged that the effect of nitrogen sources on yield components in descending order as follow: ammonia gas > ammonium nitrate $>$ urea. The superiority of ammonia gas than other two nitrogen fertilizers may due to the promoted effect of anhydrous ammonia on decreasing soil $\mathrm{pH}$ caused by injection of anhydrous ammonia which enhanced nutrient uptake. In this connection, Sommer (2005) mentioned that the roots absorbed nitrogen out of there only if they are sufficiently supplied with saccharides from the aboveground parts and plant can thus use nitrogen in metabolism of nitrogenous compounds. The roots that participate in uptake of nitrogen and ammonia from depots, (the injection of liquid ammonia fertilizer into soil in limited points of application creating socalled depots) become denser and branch due to saccharides produced in the aboveground part of plant. Also, roots distribution changes in accordance with plant growth stage and they usually grow from free soil towards depots. These results are in line with those obtained by Ismail et al (1996) and El-Masry et al (2006).

Concerning the nitrogen levels, the data show that, regardless the nitrogen sources, increasing nitrogen levels gradually increased maize yield components. In the first season, added $286 \mathrm{Kg}$ $\mathrm{N} \mathrm{ha}^{-1}$ increased number of rows/ear, number of grains/row and 100-grain weight by about $0.8,4.7$ and $8.09 \%$ when compared with $214 \mathrm{~kg} \mathrm{~N} \mathrm{ha}^{-1}$, respectively. Same trends were obtained in the second season. The promotive effect of increasing nitrogen levels on maize yield components is mainly due to merestmic activity, vegetative growth and accumulation of photosynthates resulted by nitrogen (Dubey et al., 2013). These results agree with those obtained by El-Zubair et al. (2015) and Jat et al. (2017).

\section{Grain and stover yields}

Data in Fig. (1 and 2) represent the effect of irrigation and nitrogen sources and levels on grain and stover yield of maize. It is evident from the data that irrigation treatments had significantly affected maize yields. It was observed that irrigation at 1.3 APE gave higher grain and stover yields over irrigation at 1.0 and 0.7 APE. The maximum grain and stover yields recorded in irrigation at 1.3 APE were 7.049 and $7.865 \mathrm{t} \mathrm{ha}^{-1}$ in the first season and 7.112 and $7.938 \mathrm{t} \mathrm{ha}^{-1}$ in the second one, respectively, followed by that irrigation at 1.0 PAE (6.826 and $7.754 \mathrm{t} \mathrm{ha}^{-1}$ in the first season and 6.911 and $7.858 \mathrm{t} \mathrm{ha}^{-1}$ in the second season, respectively, with no significant differences between them. On the other hand, the irrigation at 0.7 PAE yielded the lowest grain and stover yields. The higher grain and stover yields with increasing levels of irrigation might be due to the significant enhancement in yield components as mentioned before and also to the availability of water as an important factor in the plant growth. The reduction in maize yields resulted in decreasing the availability of soil moisture content ( $\mathrm{I}_{3}$ treatment) and could be attributed to water shortage (Eid et al., 2010). These results are similar to those obtained by Shinde et al. (2014) and Ewis et al. (2016).

TABLE 5. Means of yield components of maize plants as affected by irrigation schedule and nitrogen sources and levels

\begin{tabular}{|c|c|c|c|c|c|c|}
\hline \multirow{2}{*}{ Treatments } & \multicolumn{2}{|c|}{ Number of row/ear } & \multicolumn{2}{|c|}{ Number of grains/row } & \multicolumn{2}{|c|}{ 100-grain weight (g) } \\
\hline & 2016 & 2017 & 2016 & 2017 & 2016 & 2017 \\
\hline \multicolumn{7}{|l|}{ Irrigation } \\
\hline I1 (1.3 APE) & $12.98 \mathrm{~b}$ & $13.03 \mathrm{~b}$ & $45.29 \mathrm{a}$ & $45.34 \mathrm{a}$ & $30.28 \mathrm{a}$ & $29.91 \mathrm{a}$ \\
\hline $\mathrm{I} 2$ (1.0 APE) & $13.12 \mathrm{a}$ & $13.15 \mathrm{a}$ & $44.60 \mathrm{~b}$ & $44.68 \mathrm{~b}$ & $29.87 \mathrm{~b}$ & $29.96 \mathrm{a}$ \\
\hline I3 (0.7 APE) & $12.76 \mathrm{c}$ & $12.83 \mathrm{c}$ & $41.85 \mathrm{c}$ & $41.97 \mathrm{c}$ & $25.52 \mathrm{c}$ & $25.63 \mathrm{~b}$ \\
\hline \multicolumn{7}{|l|}{ N sources } \\
\hline Urea & $12.90 \mathrm{c}$ & $12.92 \mathrm{c}$ & $43.81 \mathrm{c}$ & $43.90 \mathrm{c}$ & $28.21 \mathrm{c}$ & $28.04 \mathrm{c}$ \\
\hline A. N. & $12.95 \mathrm{~b}$ & $13.00 \mathrm{~b}$ & $43.95 \mathrm{~b}$ & $44.03 \mathrm{~b}$ & $28.60 \mathrm{~b}$ & $28.44 \mathrm{~b}$ \\
\hline A. G. & $13.01 \mathrm{a}$ & $13.09 \mathrm{a}$ & $44.04 \mathrm{a}$ & $44.11 \mathrm{a}$ & $28.96 \mathrm{a}$ & $29.02 \mathrm{a}$ \\
\hline \multicolumn{7}{|l|}{ N levels } \\
\hline $214 \mathrm{~kg} / \mathrm{ha}$ & $12.90 \mathrm{~b}$ & $12.94 \mathrm{~b}$ & $42.93 \mathrm{~b}$ & $43.03 \mathrm{~b}$ & $27.44 \mathrm{~b}$ & $27.64 \mathrm{~b}$ \\
\hline $286 \mathrm{~kg} / \mathrm{ha}$ & $13.00 \mathrm{a}$ & $13.05 \mathrm{a}$ & $44.93 \mathrm{a}$ & $44.99 \mathrm{a}$ & $29.66 \mathrm{a}$ & $29.42 \mathrm{a}$ \\
\hline
\end{tabular}

Egypt. J. Soil. Sci. 59, No. 1 (2019) 

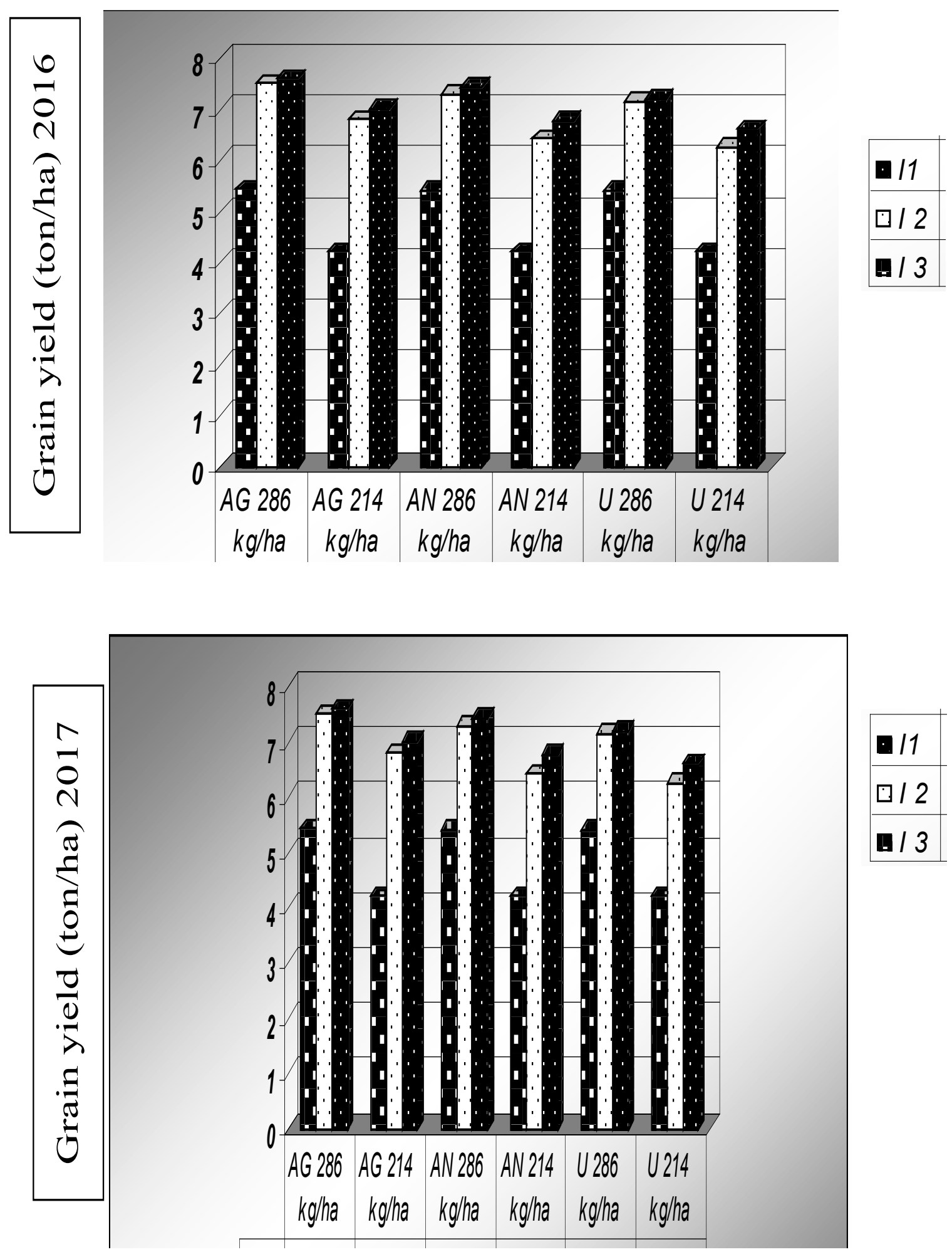

Fig. 1. Means of grain yield of maize plants as affected by irrigation schedule and nitrogen sources and levels 

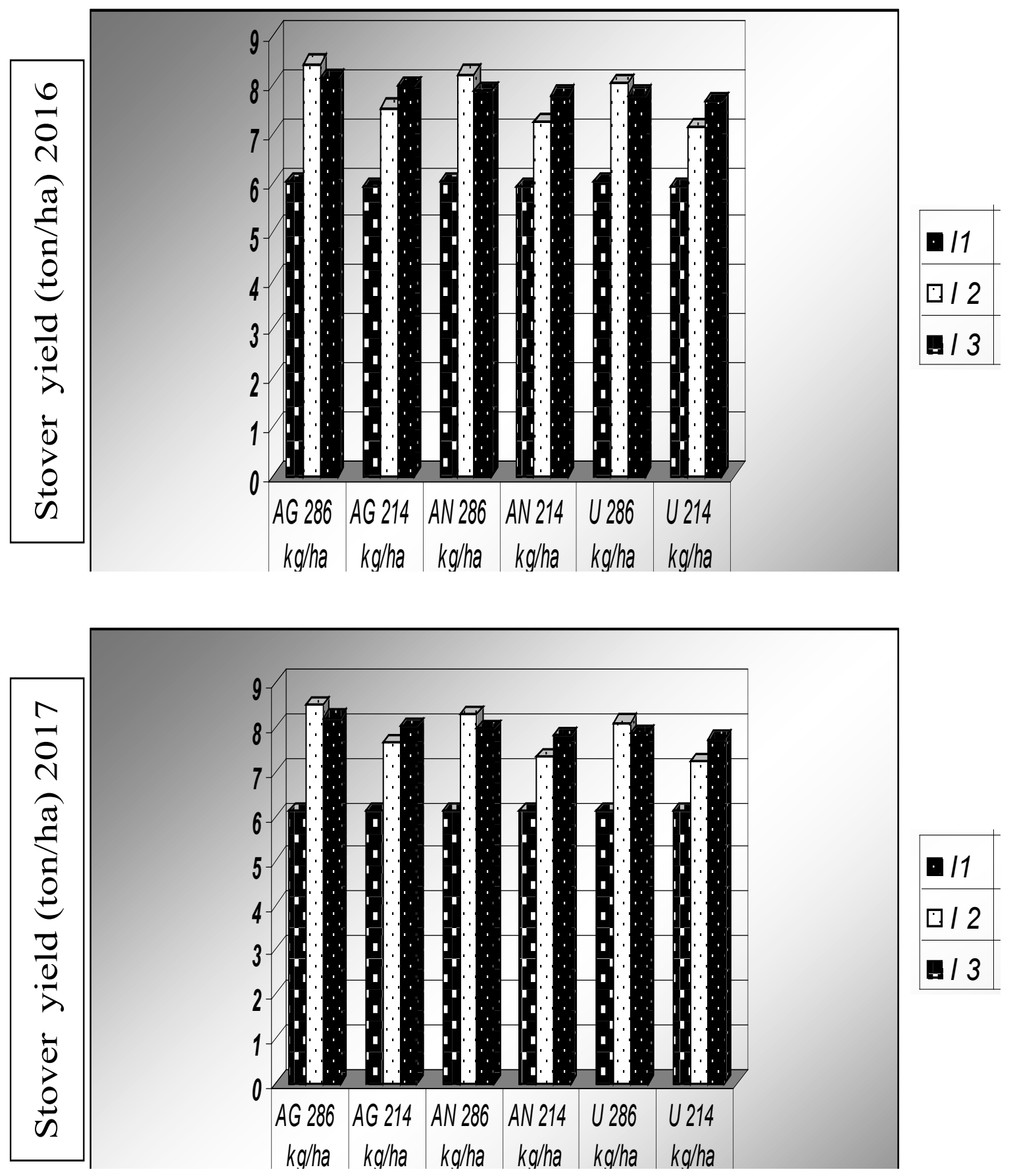

Fig. 2. Means of stover yield of maize plants as affected by irrigation schedule and nitrogen sources and levels 
As for nitrogen sources, the data show that both grain and stover yields were significantly affected by nitrogen sources. The effect of nitrogen sources on grain and stover yields could be arranged in the descending order as follows: ammonia gas $>$ ammonium nitrate $>$ urea. The superiority of ammonia gas over ammonium nitrate and urea on maize grain yield reached 2.3 and $8.5 \%$ in the first season and 3.1 and $5.1 \%$ in the second season, respectively. Similar trends were obtained for stover yields. The superiority of ammonia gas over other two sources can be explained by the improvement in soil chemical conditions and in turn enhanced yield components of maize as discussed before. In this connection Abd El-Kader (2002) mentioned that injection of ammonia caused decreases in soil $\mathrm{pH}$ after 36 hours from injection. Similar results were obtained by El-Masry et al. (2006) and Ismail et al. (2014).

Regarding nitrogen levels, data in Table 6 revealed that increasing nitrogen levels up to $286 \mathrm{~kg} \mathrm{ha}^{-1}$ significantly increased both grain and stover yields in both growing seasons. The application of $286 \mathrm{~kg} \mathrm{~N} \mathrm{ha}^{-1}$ increased grain yield by about 15.6 and $15.2 \%$ over $214 \mathrm{~kg} \mathrm{~N} / \mathrm{ha}$ in both seasons, respectively. Stover yield followed the similar pattern as grain yield. The promotive effect of increasing nitrogen levels on grain and stover yields may be due to the exuberant vegetative growth and yield components noted in the case of higher doses of nitrogen application (Shirazi et al., 2011). Similar results were obtained by AlKaisi and Yin (2003) and Markovic et al. (2017).

\section{Nitrogen, $P$ and $K$ uptake}

The data regarding nutrient uptake in grains and/or stover as affects by irrigation treatments as well as nitrogen sources and levels are given in Tables 6, 7 and 8. The increase in the available soil moisture significantly increased $\mathrm{N}, \mathrm{P}$ and $\mathrm{K}$ in grains and/or stover. The maximum total $\mathrm{N}, \mathrm{P}$ and $\mathrm{K}$ recorded with irrigation at $1.3 \mathrm{APE}$ were $203.55,51.60$ and $182.05 \mathrm{~kg} \mathrm{ha}^{-1}$ in the first season and $206.45,52,73$ and $181.23 \mathrm{~kg} \mathrm{ha}^{-1}$ in the second one, respectively. Whereas, minimum total of $126.29,30.23$ and $106.48 \mathrm{~kg} \mathrm{~N}, \mathrm{P}$ and $\mathrm{K} \mathrm{ha}^{-1}$ in the first season and $127.34,31.42$ and $110.30 \mathrm{~kg} \mathrm{~N}, \mathrm{P}$ and $\mathrm{K}$ in the second season, respectively were up taken by maize plants under $\mathrm{I}_{3}$ (deficient available moisture). It can be explained that more frequent irrigation Events increase lability of nutrients, enhance nutrients diffusion as cross section area for diffusion increases and tortuosity of path is decreased (Rahim et al., 2010). These results are similar to those obtained by Al-Kaisi and Yin (2003) and Zorkany (2014).

Data for nitrogen sources showed that $\mathrm{N}$ and $\mathrm{K}$ uptake only were significantly affected by nitrogen sources, which ammonia gas recorded the highest values, followed by ammonium nitrate. Whereas, urea exerted the lowest $\mathrm{N}$ and $\mathrm{K}$ uptake by maize grains and/or stover. This is mainly explained by the effect of nitrogen sources on grain and stover yields, since nutrient uptake calculated as multiplying yield dry weight by nutrient concentration (see Table 1 and 2 in Appendix). These results are in line with those obtained by Ismail et al. (2014).

TABLE 6. Means of N, P and $K$ uptake by maize grains as affected by irrigation and nitrogen sources and levels

\begin{tabular}{|c|c|c|c|c|c|c|}
\hline \multirow{2}{*}{ Treatments } & \multicolumn{2}{|c|}{ N (kg ha $\left.{ }^{-1}\right)$} & \multicolumn{2}{|c|}{$\mathbf{P}\left(\mathrm{kg} \mathrm{ha}^{-1}\right)$} & \multicolumn{2}{|c|}{$\mathrm{K}\left(\mathrm{kg} \mathrm{ha}^{-1}\right)$} \\
\hline & 2016 & 2017 & 2016 & 2017 & 2016 & 2017 \\
\hline \multicolumn{7}{|l|}{ Irrigation } \\
\hline I1 (1.3 APE) & $117.72 \mathrm{a}$ & $118.66 \mathrm{a}$ & $24.43 \mathrm{a}$ & $24.56 \mathrm{a}$ & $68.25 \mathrm{a}$ & $70.68 \mathrm{a}$ \\
\hline I2 (1.0 APE) & $112.22 \mathrm{~b}$ & $114.11 \mathrm{~b}$ & $22.27 \mathrm{~b}$ & $22.46 \mathrm{~b}$ & $63.96 \mathrm{~b}$ & $66.31 \mathrm{~b}$ \\
\hline I3 (0.7 APE) & $71.18 \mathrm{c}$ & $71.72 \mathrm{c}$ & $14.19 \mathrm{c}$ & $14.51 \mathrm{c}$ & $36.51 \mathrm{c}$ & $37.95 \mathrm{c}$ \\
\hline \multicolumn{7}{|l|}{ N sources } \\
\hline Urea & $96.83 \mathrm{c}$ & $98.52 \mathrm{c}$ & 20.94 & 20.83 & $52.64 \mathrm{c}$ & $55.11 \mathrm{c}$ \\
\hline A. N. & $100.30 \mathrm{~b}$ & $99.99 \mathrm{~b}$ & 20.61 & 20.55 & $56.45 \mathrm{~b}$ & $58.33 \mathrm{~b}$ \\
\hline A. G. & $104.06 \mathrm{a}$ & $105.98 \mathrm{a}$ & 20.17 & 19.93 & $59.62 \mathrm{a}$ & $61.42 \mathrm{a}$ \\
\hline \multicolumn{7}{|l|}{ N levels } \\
\hline $214 \mathrm{~kg} / \mathrm{ha}$ & $85.01 \mathrm{~b}$ & $92.90 \mathrm{~b}$ & $18.81 \mathrm{~b}$ & $20.42 \mathrm{~b}$ & $46.57 \mathrm{~b}$ & $49.12 b$ \\
\hline $286 \mathrm{~kg} / \mathrm{ha}$ & $109.62 \mathrm{a}$ & $110.12 \mathrm{a}$ & $21.70 \mathrm{a}$ & $21.71 \mathrm{a}$ & $65.97 \mathrm{a}$ & $67.48 \mathrm{a}$ \\
\hline
\end{tabular}


TABLE 7. Means of N, P and $K$ uptake by maize stover as affected by irrigation and nitrogen sources and levels

\begin{tabular}{|c|c|c|c|c|c|c|}
\hline \multirow{2}{*}{ Treatments } & \multicolumn{2}{|c|}{$\mathbf{N}\left(k g h^{-1}\right)$} & \multicolumn{2}{|c|}{$\mathbf{P}\left(\mathrm{kg} \mathrm{ha}^{-1}\right)$} & \multicolumn{2}{|c|}{$\mathbf{K}\left(\mathrm{kg} \mathrm{ha}^{-1}\right)$} \\
\hline & 2016 & 2017 & 2016 & 2017 & 2016 & 2017 \\
\hline \multicolumn{7}{|l|}{ Irrigation } \\
\hline I1 (1.3 APE) & $80.34 \mathrm{~b}$ & $81.47 \mathrm{~b}$ & $24.28 \mathrm{~b}$ & $24.28 \mathrm{~b}$ & $98.27 \mathrm{~b}$ & $100.07 \mathrm{~b}$ \\
\hline I2 (1.0 APE) & $84.92 \mathrm{a}$ & $86.83 \mathrm{a}$ & $26.22 \mathrm{a}$ & $27.24 \mathrm{a}$ & $112.93 \mathrm{a}$ & $114.66 \mathrm{a}$ \\
\hline I3 (0.7 APE) & $54.35 \mathrm{c}$ & $54.74 \mathrm{c}$ & $15.01 \mathrm{c}$ & $16.11 \mathrm{c}$ & $69.63 \mathrm{c}$ & $71.57 \mathrm{c}$ \\
\hline \multicolumn{7}{|l|}{ N sources } \\
\hline Urea & $69.52 \mathrm{c}$ & $71.46 \mathrm{~b}$ & 21.53 & 22.11 & $90.78 \mathrm{c}$ & $92.58 \mathrm{c}$ \\
\hline A. N. & $72.34 \mathrm{~b}$ & $72.24 b$ & 21.65 & 22.51 & $92.27 \mathrm{~b}$ & $93.97 \mathrm{~b}$ \\
\hline A. G. & $77.75 \mathrm{a}$ & $79.34 \mathrm{a}$ & 22.38 & 23.00 & $97.67 \mathrm{a}$ & $99.76 \mathrm{a}$ \\
\hline \multicolumn{7}{|l|}{ N levels } \\
\hline $214 \mathrm{~kg} / \mathrm{ha}$ & $67.84 \mathrm{~b}$ & $68.71 \mathrm{~b}$ & $20.16 b$ & $21.06 \mathrm{~b}$ & 86.97 b & 89.12 b \\
\hline $286 \mathrm{~kg} / \mathrm{ha}$ & $78.50 \mathrm{a}$ & $80.04 \mathrm{a}$ & $23.51 \mathrm{a}$ & $23.94 \mathrm{a}$ & $100.24 \mathrm{a}$ & $101.67 \mathrm{a}$ \\
\hline
\end{tabular}

TABLE 8. Means of N, $P$ and $K$ uptake by maize plants as affected by irrigation and nitrogen sources and levels

\begin{tabular}{|c|c|c|c|c|c|c|}
\hline \multirow{2}{*}{ Treatments } & \multicolumn{2}{|c|}{$\mathbf{N}\left(\mathrm{kg} \mathrm{ha}^{-1}\right)$} & \multicolumn{2}{|c|}{ P $\left(\mathrm{kg} \mathrm{ha}^{-1}\right)$} & \multicolumn{2}{|c|}{$K\left(\mathrm{~kg} \mathrm{ha}^{-1}\right)$} \\
\hline & 2016 & 2017 & 2016 & 2017 & 2016 & 2017 \\
\hline \multicolumn{7}{|l|}{ Irrigation } \\
\hline I1 (1.3 APE) & $198.06 \mathrm{a}$ & $200.13 \mathrm{a}$ & $48.71 \mathrm{a}$ & $48.78 \mathrm{a}$ & $166.52 \mathrm{~b}$ & $170.86 \mathrm{~b}$ \\
\hline I2 (1.0 APE) & $197.16 \mathrm{a}$ & $200.94 \mathrm{a}$ & $48.53 \mathrm{a}$ & $49.70 \mathrm{a}$ & $176.88 \mathrm{a}$ & $180.98 \mathrm{a}$ \\
\hline I3 (0.7 APE) & $126.29 \mathrm{~b}$ & $127.34 \mathrm{~b}$ & $30.23 \mathrm{~b}$ & $31.54 \mathrm{~b}$ & $106.48 \mathrm{c}$ & $110.30 \mathrm{c}$ \\
\hline \multicolumn{7}{|l|}{$\mathbf{N}$ sources } \\
\hline Urea & $167.26 \mathrm{c}$ & $170.79 \mathrm{c}$ & 43.11 & 43.86 & $144.39 \mathrm{c}$ & $148.21 \mathrm{~b}$ \\
\hline A. N. & $171.59 \mathrm{~b}$ & $173.23 \mathrm{~b}$ & 43.18 & 43.92 & $149.64 \mathrm{~b}$ & $148.18 \mathrm{~b}$ \\
\hline A. G. & $182.64 \mathrm{a}$ & $186.19 \mathrm{a}$ & 44.21 & 44.04 & $158.39 \mathrm{a}$ & $162.14 \mathrm{a}$ \\
\hline \multicolumn{7}{|l|}{ N levels } \\
\hline $214 \mathrm{~kg} / \mathrm{ha}$ & $159.28 \mathrm{~b}$ & $161.96 \mathrm{~b}$ & $39.29 \mathrm{~b}$ & $40.70 \mathrm{~b}$ & $133.88 \mathrm{~b}$ & $138.53 \mathrm{~b}$ \\
\hline $286 \mathrm{~kg} / \mathrm{ha}$ & $188.39 \mathrm{a}$ & $190.40 \mathrm{a}$ & $46.34 \mathrm{a}$ & $45.95 \mathrm{a}$ & $166.52 \mathrm{a}$ & $169.81 \mathrm{a}$ \\
\hline
\end{tabular}

Considering nitrogen levels, the data clearly show that, regardless nitrogen sources, N, P and $\mathrm{K}$ uptake in grains and/or stover were markedly affected by nitrogen levels. Addition of $286 \mathrm{~kg} \mathrm{~N}$ $\mathrm{ha}^{-1}$ yielded total $\mathrm{N}, \mathrm{P}$ and $\mathrm{K}$ surpassed that due to $214 \mathrm{~kg} \mathrm{~N}^{-1}$ by about $19.0,17.7$ and $33.3 \%$ in the first season. Similar trends were obtained in the second season as well as N, P and K uptake by grains or stover in both seasons. The increment of $\mathrm{N}$, $\mathrm{P}$ and $\mathrm{K}$ uptake resulted in increasing nitrogen levels may be due to the effect of nitrogen levels on grains or stover as mentioned before. Also, this increase might be attributed to the increase in root surface per soil unit volume due to nitrogen application and accordingly increased the rate of nutrients absorption (Hassanien, 2009). These results are in harmony with those obtained by Ismail et al. (1999) and Gebraiel et al. (2005).

\section{Crop-water relations}

Seasonal applied irrigation water (IW)

Data in table 9 show the amount of seasonal applied water. The data revealed that, regardless the adapted nitrogen sources and levels, watering at 1.3 of APE $\left(\mathrm{I}_{1}\right)$ resulted in higher amount of applied irrigation water found to be 8000 and $7750 \mathrm{~m}^{3} \mathrm{ha}^{-1}$ in both seasons, respectively. On the other hand, watering at $1.0\left(\mathrm{I}_{2}\right)$ and $0.7\left(\mathrm{I}_{3}\right)$ of APE found to be 7010 and 6110 in the first season, and 6820 and $5920 \mathrm{~m}^{3} \mathrm{ha}^{-1}$ in the second one, respectively. The applied water (IW) at 0.7 , 1.0 and 1.3 of A.P.E. were distributed through 5, 6 and 7 irrigation events including sowing and first irrigation in both seasons. The reduction in seasonal applied water due to decrease in the A.P.E. is mainly attributed to the decrease of irrigation events. It is worthy to notice that, seasonal applied irrigation water did not respond to both nitrogen sources or levels. These results agree with those results obtained by El-Bably (2007), Eid et al. (2010) and Zorkany (2014).

Egypt. J. Soil. Sci. 59, No. 1 (2019) 
TABLE 9. Means of seasonal applied water, seasonal consumptive use, water utilization efficiency and water use efficiency as affected by irrigation treatments and nitrogen sources and levels

\begin{tabular}{|c|c|c|c|c|c|c|c|c|}
\hline \multirow[t]{2}{*}{ Treatments } & \multicolumn{2}{|c|}{$\begin{array}{l}\text { Seasonal applied } \\
\text { water }\left(\mathbf{m}^{3} \mathbf{h a}^{-1}\right)\end{array}$} & \multicolumn{2}{|c|}{$\begin{array}{c}\text { Seasonal consumptive } \\
\text { use }\left(\mathrm{m}^{3} \mathrm{ha}^{-1}\right)\end{array}$} & \multicolumn{2}{|c|}{$\begin{array}{l}\text { Water utilization } \\
\text { efficiency } \\
\left(\mathrm{kg} \mathrm{m}^{-3}\right)\end{array}$} & \multicolumn{2}{|c|}{$\begin{array}{l}\text { Water use } \\
\text { efficiency } \\
\left(\mathrm{kg} \mathrm{m}^{-3}\right)\end{array}$} \\
\hline & 2016 & 2017 & 2016 & 2017 & 2016 & 2017 & 2016 & 2017 \\
\hline \multicolumn{9}{|l|}{ Irrigation } \\
\hline I1 (1.3 APE) & 8000 a & $7750 \mathrm{a}$ & 6927 a & $7084 \mathrm{~b}$ & $0.88 \mathrm{~b}$ & $0.92 \mathrm{~b}$ & $1.02 \mathrm{~b}$ & $1.01 \mathrm{~b}$ \\
\hline I2 (1.0 APE) & $7010 \mathrm{~b}$ & $6820 \mathrm{~b}$ & $6937 \mathrm{a}$ & $7150 \mathrm{a}$ & $0.98 \mathrm{a}$ & $1.02 \mathrm{a}$ & $0.99 \mathrm{c}$ & $0.95 \mathrm{c}$ \\
\hline I3 (0.7 APE) & $6110 \mathrm{c}$ & $5920 \mathrm{c}$ & $4886 \mathrm{~b}$ & $4585 \mathrm{c}$ & $0.78 \mathrm{c}$ & $0.82 \mathrm{c}$ & $1.08 \mathrm{a}$ & $1.05 \mathrm{a}$ \\
\hline \multicolumn{9}{|l|}{ N sources } \\
\hline Urea & 7040 & 6830 & $5823 \mathrm{c}$ & $6038 \mathrm{c}$ & $0.86 \mathrm{c}$ & $0.90 \mathrm{c}$ & $1.05 \mathrm{a}$ & $1.03 \mathrm{a}$ \\
\hline A. N. & 7040 & 6830 & $6077 \mathrm{~b}$ & $6235 \mathrm{~b}$ & $0.88 \mathrm{~b}$ & $0.92 \mathrm{~b}$ & $1.03 \mathrm{~b}$ & $1.01 \mathrm{~b}$ \\
\hline A. G. & 7040 & 6830 & 6349 a & $6546 \mathrm{a}$ & $0.90 \mathrm{a}$ & $0.94 \mathrm{a}$ & $1.01 \mathrm{c}$ & $0.99 \mathrm{c}$ \\
\hline \multicolumn{9}{|l|}{ N levels } \\
\hline $214 \mathrm{~kg} / \mathrm{ha}$ & 7040 & 6830 & $5564 \mathrm{~b}$ & $5758 \mathrm{~b}$ & $0.81 \mathrm{~b}$ & $0.85 \mathrm{~b}$ & $1.04 \mathrm{a}$ & $1.02 \mathrm{a}$ \\
\hline $286 \mathrm{~kg} / \mathrm{ha}$ & 7040 & 6830 & $6602 \mathrm{a}$ & $6787 \mathrm{a}$ & $0.94 \mathrm{a}$ & $0.99 \mathrm{a}$ & $1.01 \mathrm{~b}$ & $0.99 \mathrm{~b}$ \\
\hline
\end{tabular}

\section{Seasonal consumptive use (CU)}

Mean values of seasonal consumptive use as affected by irrigation and nitrogen treatments for maize are presented in Table 9. Plants irrigated through 1.3 of A.P.E $\left(\mathrm{I}_{1}\right)$ was accompanied with the highest seasonal consumptive use with an amount of 6927 and $7084 \mathrm{~m}^{3} \mathrm{ha}^{-1}$ in both seasons, respectively, followed by $\mathrm{I}_{2}$ with6937 and 7150 $\mathrm{m}^{3} \mathrm{ha}^{-1}$ in both seasons, respectively. Whereas, $\mathrm{I}_{3}$ treatment exhibited the lowest seasonal consumptive use (4886 and $4585 \mathrm{~m}^{3} \mathrm{ha}^{-1}$ in the two studied seasons, respectively). These results indicated that water consumptive use increased as soil moisture was maintained high by frequent irrigation. Also, it could be explained by higher frequent of irrigations provide chance for more consumption of water ultimately resulted in increasing transpiration and evaporation from the soil surface (Eid et al, 2010). Similar results were obtained by El-Tantawy et al. (2007).

Water utilization efficiency (WUtE, $\mathrm{kg} \mathrm{m}$-3)

Water utilization efficiency or productivity of maize grains $\left(\mathrm{kg} \mathrm{m}^{-3}\right)$ obtained from each cubic meter of water consumed as affected by irrigation scheduling, nitrogen sources and nitrogen levels is presented in Table 9. Results indicate that the highest values of WUtE were obtained under the irrigation at 1.0 of A.P.E $\left(\mathrm{I}_{2}\right)$, followed by irrigation at 1.3 of A.P.E $\left(\mathrm{I}_{1}\right)$. Whereas the irrigation at 0.7 of A.P.E $\left(\mathrm{I}_{3}\right)$ exhibited the lowest WUtE. These results could be attributed to the higher grain yield under $I_{2}$ treatment comparable to $I_{1}$ and $\mathrm{I}_{3}$ treatments. Similar results were obtained by Hegab et al. (2014) and Ewis et al. (2015).
As for nitrogen sources, the results showed that water utilization efficiency was significantly affected by nitrogen sources. The effect of the studied nitrogen sources on WUtE could be arranged in the descending order as follow: ammonia gas $>$ ammonium nitrate $>$ urea fertilizer. These results could be explained by the effect of these fertilizers on maize grain yield, since seasonal applied water was constant for each fertilizer sources.

Considering nitrogen levels, the data clearly showed that increasing nitrogen level from 214 to $286 \mathrm{~kg} \mathrm{ha}^{-1}$ had a positive effect on water utilization efficiency in both seasons, which mainly due to the increment of grain yield with increasing nitrogen level. The relative increasing of water utilization efficiency due to $286 \mathrm{~kg} \mathrm{~N} \mathrm{ha}^{-1}$ reached to 16.0 and $16.5 \%$ over $214 \mathrm{~kg} \mathrm{~N} \mathrm{ha}^{-1}$ in both seasons, respectively. These results agree with those obtained by Eid et al. (2010) and Ewis et al. (2016).

\section{Water use efficiency (WUE, $\mathrm{kg} \mathrm{m}$-3)}

Water use efficiency (WUE) is a parameter which indicates the capability of plants to utilize the soil moisture stored in the effective root zone. The water use efficiency as affected by irrigation scheduling and nitrogen sources and levels are shown in Table (9). The results revealed that irrigation at 0.7 of A.P.E. $\left(\mathrm{I}_{3}\right)$ gave the highest values of WUE (1.08 and $1.05 \mathrm{~kg}$ grains $\mathrm{m}^{-3}$ in both seasons, respectively), followed by irrigation at 1.3 of A.P.E. (1.02 and $1.01 \mathrm{~kg}$ maize grains $\mathrm{m}^{-3}$ in the two seasons. On the other hand, irrigation 
at 1.0 of A.P.E. produced the lowest water use efficiency $\left(0.94\right.$ and $0.95 \mathrm{~kg}$ grains $\mathrm{m}^{-3}$ in both seasons, respectively). The superiority of the effect of $\mathrm{I}_{3}$ treatment is mainly due to the reduction in seasonal applied water. However, the reduction in WUE under $\mathrm{I}_{2}$ treatment is attributed to the higher water availability which can reduce the amount and efficiency of water (Maman et al. 2003). In this regard Ehdaie et al. (1991) and Ebdon et al. (1998) who mentioned that the amount of water used and water use efficiency vary with climatic, soil conditions and the ability of the crops to extract water stored in soil. These results are in line with those obtained by Zorkany (2014).

As for nitrogen sources, the data indicated that water use efficiency was significantly responded to nitrogen sources. The effect of nitrogen sources on water use efficiency could be arranged in the descending order as follow: urea $>$ ammonium nitrate $>$ ammonia gas. These results may be due to the effect of different nitrogen fertilizers on seasonal consumptive use (Ewis et al., 2016). Regarding nitrogen level, the data revealed that

\section{Appendix}

increasing nitrogen level from 214 to $286 \mathrm{~kg}$ $\mathrm{ha}^{-1}$ positively decreased water use efficiency. These results are mainly explained by the effect of nitrogen on improving the growth of roots and shoots of maize, consequently improved water absorption (Ewis et al., 2016). These results coincided with those obtained by Yang et al. (2005), El-Atawy (2007) and Eid et al. (2010).

\section{Conclusion}

The results of this investigation showed that the highest grain and stover yields of maize plants were obtained when plants were irrigated using 1.0 or 1.3 pan evaporation coefficient with no significant differences between them. However, the highest water productivity was obtained under irrigation with 1.0 pan evaporation coefficient which means that the possibility to save about $960 \mathrm{~m}^{3} \mathrm{ha}^{-1}$ from the applied irrigation water with slightly insignificant reduction in maize yields. Therefore, it is recommended to apply irrigation water using 1.0 of A.P.E. and fertilized maize plants with anhydrous ammonia at the rate of 286 $\mathrm{kg} \mathrm{N}^{-1}$ to maximize maize production and save irrigation water.

TABLE 1. Means of $N, P$ and $K$ concentration in maize grains plants as affected by irrigation and nitrogen sources and levels

\begin{tabular}{lcccccc}
\hline \multicolumn{1}{c}{ Treatments } & $\mathbf{2 0 1 6}$ & $\mathbf{2 0 1 7}$ & $\mathbf{2 0 1 6}$ & $\mathbf{2 0 1 7}$ & $\mathbf{2 0 1 6}$ & $\mathbf{2 0 1 7}$ \\
\hline Irrigation & & & & & & K\% \\
I1 (1.3 APE) & $1.65 \mathrm{a}$ & $1.66 \mathrm{a}$ & $0.33 \mathrm{a}$ & $0.34 \mathrm{a}$ & $0.98 \mathrm{a}$ & $0.97 \mathrm{a}$ \\
I2 (1.0 APE) & $1.64 \mathrm{a}$ & $1.65 \mathrm{a}$ & $0.33 \mathrm{a}$ & $0.33 \mathrm{a}$ & $0.88 \mathrm{a}$ & $0.89 \mathrm{a}$ \\
I3 (0.7 APE) & $1.48 \mathrm{~b}$ & $1.48 \mathrm{~b}$ & $0.28 \mathrm{~b}$ & $0.28 \mathrm{~b}$ & $0.75 \mathrm{~b}$ & $0.76 \mathrm{a}$ \\
N sources & & & & & & \\
Urea & $1.58 \mathrm{~b}$ & $1.59 \mathrm{~b}$ & 0.31 & 0.32 & $0.84 \mathrm{~b}$ & $0.86 \mathrm{~b}$ \\
A. N. & $1.59 \mathrm{~b}$ & $1.58 \mathrm{~b}$ & 0.32 & 0.32 & $0.84 \mathrm{~b}$ & $0.86 \mathrm{~b}$ \\
A. G. & $1.61 \mathrm{a}$ & $1.62 \mathrm{a}$ & 0.32 & 0.32 & $0.90 \mathrm{a}$ & $0.91 \mathrm{a}$ \\
N levels & & & & & & \\
214 kg/ha & $1.56 \mathrm{~b}$ & $1.56 \mathrm{~b}$ & 0.31 & 0.31 & $0.77 \mathrm{~b}$ & $0.79 \mathrm{~b}$ \\
286 kg/ha & $1.62 \mathrm{a}$ & $1.62 \mathrm{a}$ & 0.31 & 0.31 & $0.94 \mathrm{a}$ & $0.96 \mathrm{a}$ \\
\hline
\end{tabular}

TABLE 2. Means of N, $P$ and $K$ concentration in maize stover plants as affected by irrigation and nitrogen sources and levels

\begin{tabular}{|c|c|c|c|c|c|c|}
\hline \multirow{2}{*}{ Treatments } & \multicolumn{2}{|c|}{ N\% } & \multicolumn{2}{|c|}{$\mathbf{P \%}$} & \multicolumn{2}{|c|}{ K\% } \\
\hline & 2016 & 2017 & 2016 & 2017 & 2016 & 2017 \\
\hline \multicolumn{7}{|l|}{ Trrigation } \\
\hline I1 (1.3 APE) & $1.08 \mathrm{a}$ & $1.09 \mathrm{a}$ & $0.33 \mathrm{a}$ & $0.34 \mathrm{a}$ & $1.44 \mathrm{a}$ & $1.45 \mathrm{a}$ \\
\hline I2 (1.0 APE) & $1.01 \mathrm{a}$ & $1.00 \mathrm{a}$ & $0.30 \mathrm{~b}$ & $0.30 \mathrm{~b}$ & $1.24 \mathrm{~b}$ & $1.25 \mathrm{~b}$ \\
\hline $\begin{array}{l}\mathrm{I} 3(0.7 \mathrm{APE}) \\
\mathbf{N} \text { sources }\end{array}$ & $0.87 \mathrm{a}$ & $0.88 \mathrm{a}$ & $0.24 \mathrm{c}$ & $0.25 \mathrm{c}$ & $1.15 \mathrm{~b}$ & $1.15 \mathrm{~b}$ \\
\hline Urea & $0.96 \mathrm{~b}$ & $0.96 \mathrm{~b}$ & 0.29 & 0.30 & $1.26 \mathrm{~b}$ & $1.28 \mathrm{~b}$ \\
\hline A. N. & $0.96 \mathrm{~b}$ & $0.98 \mathrm{~b}$ & 0.29 & 0.30 & $1.26 \mathrm{~b}$ & $1.27 \mathrm{~b}$ \\
\hline A.G. & $1.03 \mathrm{a}$ & $1.04 \mathrm{a}$ & 0.29 & 0.29 & $1.35 \mathrm{a}$ & $1.31 \mathrm{a}$ \\
\hline $214 \mathrm{~kg} / \mathrm{ha}$ & $0.93 \mathrm{~b}$ & $0.93 \mathrm{~b}$ & 0.27 & 0.28 & $1.22 \mathrm{~b}$ & $1.23 \mathrm{~b}$ \\
\hline $286 \mathrm{~kg} / \mathrm{ha}$ & $1.04 \mathrm{a}$ & $1.05 \mathrm{a}$ & 0.30 & 0.30 & $1.33 \mathrm{a}$ & $1.33 \mathrm{a}$ \\
\hline
\end{tabular}

Egypt. J. Soil. Sci. 59, No. 1 (2019) 


\section{References}

Abd El-Hafeez, A. M., Awadalla, H. A. and Ismail, S. A. (2013) Influence of different sources and levels of nitrogen and rock phosphate addition on maize productivity and soil fertility. J. Soil Sci. and Agric. Eng., Mansoura Univ., 4 (11), 1313-1328.

Abd El-Kader, M. G. (2002) Response of growth and yield of wheat (cv sids 7) to $\mathrm{Fe}$ and $\mathrm{Zn}$ application under ammonia injection. Ph. D. Thesis, Fac. of Agric. Moshtohor, Zagazig Univ. Egypt.

Ali, M. E., Ismail, S. A., El-Hameid, A. H., ElHussieny, O. H. M. and El-Sheref, G. F. H. (2012) Effect of natural fertilizers under different levels of nitrogen and farmyard manure on productivity of maize. Fayoum J. Agric. Res.\& Dev., 26 (1), 49-63.

Al-Kaisi, M. M. and Yin, X. (2003) Effects of Nitrogen Rate, Irrigation Rate, and Plant Population on Corn Yield and Water Use Efficiency. Agron. J. 95,14751482.

AOAC (1990) Official Methods of Analysis, $15^{\text {th }}$ ed. Association of Official analytical chemists. Washington D.C.

Ashraf, M., Saeed, M. M. and Asghar, M. N. (2002) Evaporation Pan: A Tool for Irrigation Scheduling. J. of Drain. Wat. Mana., 6 (1), 45-51.

Azizian, A. and Sepaskhah, A. R. (2014) Maize response to different water, salinity and nitrogen levels: agronomic behavior. International $J$. of Plant Production 8 (1), 107-129.

Dubey, A., Rathi, G. S. and Sahu, R. (2013) Effect of nitrogen levels on green fodder yield of oat (Avena sativa L.) varieties. Forage Research; 39, 39-41.

Ebdon, J. S., Petrovic, A. M. and Dawson, T. E. (1998) Relationship between carbon isotope discrimination, water use efficiency and evapotranspiration in Kentucky bluegrass. Crop Science 38, 157-162.

Eck, H. V. (1984) Irrigated corn yield response to nitrogen and water. Agron. J. 76, 421-428.

Ehdaie, B., Hall, A. E., Farquhar, G. D., Nguyen, H. T. and Waines, J. G. (1991) Water use efficiency and carbon isotope discrimination in wheat. Crop Science 31, 1282-1288.

Eid, S. M., El-Atawy, Gh. Sh. and EL-Shreif, M. A. (2010) Yield and some water relation of maize crop as influenced by irrigation scheduling and nitrogen fertilization rates at Middle North Delta. J. Soil Sci. and Agric. Engineering, Mansoura Univ., Vol. 1 (8), $801-813$.
El-Atawy, E. E. I. (2007) Irrigation and fertilization management under the conditions of Kafr ElSheikh Governorate soil. Ph. D Thesis, Soil Dept, Fac. of Agric., Mansoura Univ., Egypt.

El-Bably A. Z. (2007) Irrigation scheduling of some maize cultivars using class A pan evaporation in north delta Egypt. Bull. Fac., Agric., Cairo Univ., 58 (3), 222-232.

El-Masry, A. A., Gohar, N. and El-Akabawy, M. A. (2006) The influence of nitrogenous fertilizer sources and some soil amendments on hull-less barley under alkali soil conditions. Egypt. J. of Appl. Sci., 21(11).

EL-Sharkawy Anal F., Khalil, F.A.F. and Abd Elmaksoud, H.H. (2006) Effect of incorporating wheat crop residues into the soil, N-eate and irrigation interval on maize yield and some yield water relations. Minufiya J. Agric. Res. Vol. 31 , No 6, 1361-1373.

El-Tantawy, M.M., Ouda, S. A. and Khalil, F.A. (2007) Irrigation scheduling for maize crop grown under middle Egypt conditions. Res. J. Agric. and Biol. Sci., 3, 456-62.

El-Zubair, R. M., Fadlalla, B., Hussien, A. H. M. and Abdelkreim, M. (2015) Effect of different nitrogen fertilization levels on yield of maize (Zea mays L.) as winter forage. IJSTR 4 (10), 197-201.

Ewis, M. M., Abd El-Latif, K. M. and Badawi, M. I. (2015) Effect of irrigation interval and phosphorus fertilization rate on faba bean (Vicia faba L.) yield, yield components and some crop-water relationships. J. Soil Sci. and Agric. Eng., Mansoura Univ., 6 (5), 705-718.

Ewis, M. M., Abd El-Latif, K. M. and Badawi, M. I. (2016) Response of maize (Zea mays L.) to moisture stress under different nitrogen fertilization levels. J. Soil Sci. and Agric. Eng., Mansoura Univ., 7(11), 865-872.

Faki, H. H. (1991) Water allocation and its effect on faba bean technology adoplion in Shendi area. Pag 72-75in Nile Valley Regional program on CoolSeason Food Leggumes and Wheat. Annual Report 1990/91, Sudan. ICARDA/ NVRPOC-017.

FAO (2003) Unlocking the Water Potential of Agriculture. FAO, Coreporate Document Repository. 260 pp.

Fashina, A. S., Olatunji, K. A. and Alasiri,K. O. (2002) Effects of different plant population and poultry manure on yield of Ugu (Telfairia occidentalis) in

Egypt. J. Soil. Sci. 59, No. 1 (2019) 
Lagos State, Nigeria in Proceedings of the annual Conference of Horticultural Society of Nigeria (HORTON), pp. 123-127.

Galbiatti, J. A., Borges, M.J., Bueno, L.F., Garcia, A. and Vieira, R.D. (2004) Effect of different irrigation periods in the development, yield and seedling quality in the maize (Zea mays L.) crop. Engenharia Agricola.

Gebraiel, M. Y., Gohar, M. N., Salem, F. S. and Wahba, H. W. A. (2005) Vegetative growth and yield of maize (Zea mays L.) as affected by nitrogen, potassium and zinc fertilization. Egypt. J. Appl. Sci., 20 (28), 739-755.

Gurpreet, S.A., K.V. Krishan and S.S. Maha (2013) Effect of different irrigation regimes and nitrogen levels on growth parameters and yield of late kharif sown maize (Zea mays L.). Crop Res. 45 (1,2\& 3): 96-105.

Hafiz, Y. A. M. and Ewis, M. M. (2015) Effect of irrigation regime and potassium fertilizer rates on growth, yield, oil composition and some water relations of fennel plant (Foeniculum vulgare Mill) under Middle Egypt conditions. Bull. Fc. Agric., Cairo Univ., 66, 142-155.

Hassanien, A. M. M. (2009) Nitrogen fertilizer requirements for corn in newly reclaimed land. M. Sc. Thesis, Fac. of Agric., Minia Univ., Egypt.

Hegab, A. S. A., Fayed,M. T. B., Hamada, M. M. A. and Abdrabbo, M. A. A. (2014) Productivity and irrigation requirements of faba bean in North Delta of Egypt in relation to planting dates. Annals of Agricultural Sci., 59 (2), 185-193.

Igbal, A., Ayoub, M., Zaman, H. and Ahmed, R. (2006) Impact of nutrient management and legumes association on agro qualitative traits of maize forage Pak. J. Bot. 38, 1079-1084.

Ismail, S. A., Abd El-Hafeez, A. M. and Galal, O. A. (2014) Response of soybean (Glycine $\max$ L.) to microbial inoculation under chemical fertilization: 1- nodulation, yield and its components. Egypt. J. of Appl. Sci., 29 (12B), 1237-1258.

Ismail, S. A., Osman, A. Z. and El-Hamed, A. M. (1996) Effect of ammonia gas injection in alluvial soil with different rates, plant population and their interaction on garlic plants (Allium sativum L.). Egypt. J. Appl. Sci., 11 (1), 151-160.

Ismail, S.A., Morsy, M.A., Omran, A.A. and Foaad, M.M. (2006) The productivity of some hybrids
(Zea mays L.) grown in an alluvial soil under different nitrogen sources and levels. The Second Conference on Farm Integrated Pest Management. Fac. of Agric. Fayum Univ., 16-18.

Ismail, S.A., Morsy, M.A., Awad, S.S. and Salem, F.S. (1999) Effect of some maize varieties, nitrogen fertilization levels and zinc application on grain and stalk, yields, total $\mathrm{N}$ and $\mathrm{Zn}$ uptake and protein content. Fayoum J. Agric., Res. \& Dev., 13(1), 57-68.

Israelsen, O. W. and Hansen,V. E. (1962) Irrigation Principles and Practices. $3^{\text {rd }}$ ed., John Willy and Sons. Inc., New York.

Jat, H., Kaushik, M. K., Nepalia, V. and Singh, D. (2017) Effect of irrigation schedule and nitrogen fertilization on growth, yield and quality of fodder oat (Avena sativa L.). Journal of Pharmacognosy and Phytochemistry, 2017; 6(4), 2040-2042.

Khalil, F. A. F. and Mohamed,S. G. (2006) Studies on the interrelation among irrigation and maize varieties on yield and water relations using some statistical procedures. Ann. Agric. Sci. Moshtouhor, 44 (1), 393-406.

Klute, A. (1986) Methods of Analysis. $2^{\text {nd }}$ ed. Part 1: Physical and Mineralogical Methods. American Society of Agronomy, Mudision, Wisconsin, USA.

Kuchenbuch, R. O., Ingram, K. T. and Buczko,U. (2006) Effects of decreasing soil water content on seminal and lateral roots of young maize plants. Journal of Plant nutrition and Soil Science, 169, 814-848.

Maman, N., Lyon, D. J., Mason,S. C. , Galusha, T. D. and Higgins, R. (2003) Pearl millet and grain sorghum yield response to water supply in Nebraska. Agronomy J. 95, 1618-1624.

Markovic, M., Josipovic, M., Sostaric, J., Jambrovic, A. and Brkic, A. (2017) Response of maize (Zea mays L.) grain yield and yield components to irrigation and nitrogen fertilization. J. Central European Agric., 18 (1), 55-72.

Martin, D.L., Watts, D.G., Mielke, L.N., Frank, K.D. and Eisenhauer, D.E. (1982) Evaluation of nitrogen and irrigation management for corn production using water high in nitrate. Soil Sci. Soc. Am. J. 46,1056-1062.

Michael A. M. (1978) Irrigation-Theory and practices. Vikas Publishing House, New Delhi, India. 
Nilahyana, A., Islam, M. A., Mesbah, A. O. and Garcia, A. G. (2018) Effect of irrigation and nitrogen fertilization strategies on silage corn grown in semi-arid conditions. J. of Agronomy, 8, 208, 1-14.

Norwood, C. A. (2000) Water use and yield of limitedirrigated and dryland corn. Soil Sci. Soc. Am. J. 64, 365-370. [Abstract/Free Full Text].

Obi, C. O., Nnabude, P. C. and Onucha,E. (2005) Effects of kitchen waste compost and tillage on soil chemical properties and yield of Okra (Abelmuschus esculentus), Soil Sci., 15, 69-76.

Page, A. L., Miller, R. H. and Keeny, D. R. (1982) Methods of Soil Analysis. $2^{\text {nd }}$ ed. Part 2: Chemical and Microbiological Properties. American Society of Agronomy, Madisons, Wisconsin, USA.

Rahim, A., Rahamtullah, A. M. R. and Waraich, E. A. (2010) Effect of phosphorus application and irrigation scheduling on wheat yield and phosphorus use efficiency. Soil \& Environ. 29 (1), $15-22,2010$.

Sadik, M.K., Ismail,S.A., El-Hussieny, O.H.M. and Hashem, R.F. (2009) Influence of levels and methods of some organic and inorganic fertilizatiers application on maize: 1- Growth and nutrients uptake. J. Agric. Sci., Mansoura Univ., 34 (7), 9001-9014.

Sajedi, N. A., Ardakani, M. R., Naderi, A., Madani, H., Mashhadi, A. and Boojar, M. (2009) Response of maize to nutrients foliar application under water deficit stress conditions. Am. J. Agric. Biol. Sci., 4(3), 242248.

Sangakkara, U. R.,Amarasekera, P. and Stamp, P. (2010) Irrigation regimes affect early root development, shoot growth and yields of maize (Zea mays L.) in tropical minor seasons. Plant Soil and Environment 56, 2010 (5), 228-234.

Shinde, S.A., Patange, M. J. and Dhage,S. J. (2014) Influence of irrigation schedules and integrated nutrient management on growth, yield and quality of rabi maize (Zea mays L.). Int. J. Curr.Microbiol. App.Sci. (2014) 3(12), 828-832.

Shirazi, S. M., Sholichin, M., Jamee, M., Akib, Sh. and Aziz, M. (2011) Effects of different irrigation regimes and nitrogenous fertilizer on yield and growth parameters of maize. International Journal of Physical Sciences Vol. 6 (4), pp. 677-683, 18 February, 2011.

Snedecor, G. W. and Cochran,W. G. (1980) "Statistical Methods" $7^{\text {th }}$ ed. Iowa State Univ., Press, Iowa, USA.

Sommer, K. (2005) CULTAN - fertilization. Verlag Th. Mann, Gelsenkirchen, 218. (In German).

Stefano, P., Dris, R. and Rapparini, F. (2004) Influence of growing conditions and yield and quality of cherry. II. Fruit. J. Agric. And Env., 2, 307-309.

Tayel, M.Y., El Gindy, A.M., Abd- El- Hady, M. and Ghany, H.A. (2007) Effect of irrigation systems on: yield, water and fertilizer use efficiency of grape. Applied Sciences Research, 3 (5), 367-372.

Vites, F. G. (1965) Increasing water use efficiency by soil management in plant environment and efficient water use. J. Amer. Soc. Agron., 26, 537-546.

Wang, X. and Xing, Y. (2017) Effects of irrigation and nitrogen on maize growth and yield components. (C) Springer International Publishing AG 2017: 63-74.

Yang, T., Liang, Z. S., Xue, J. and Kang, S. (2005) Diversity of water use efficiency in various maize varieties. Transaction of the Chinese Society of Agricultural Engineering. 21 (10), 21-25.

Zorkany, E. S. K. (2014) Scheduling irrigation of corn (Zea mays) using the evaporation pan methods under different potassium levels. Ph. D. Thesis, Fac. of Agric. Minia Univ. Egypt.

(Received: 16/1/2019; accepted:13/ 3 /2019) 


\section{جدوله الرى ومصادر ومستويات مختلفة للنيتروجين لانتاجية محصول الأرة الثامية وبعض} العلاقات المائية

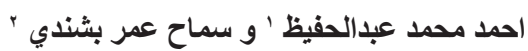

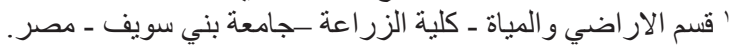

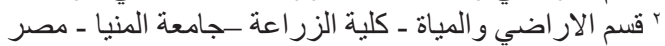

أجريت هذة الدر اسة بمزر عة محطة البحوث الزر اعية بسدس- محافظة بنى سويف ـ مصر خدر خلال موسمى النمو

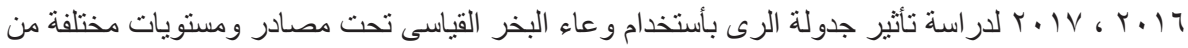

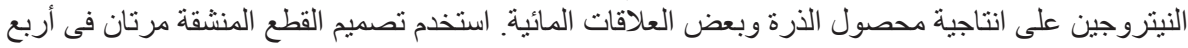

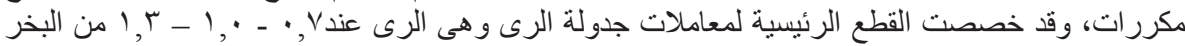

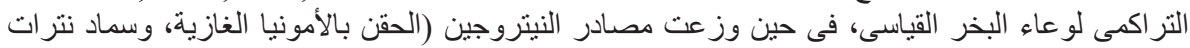

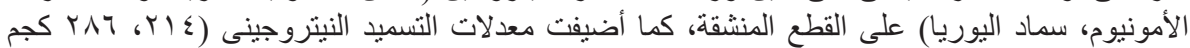

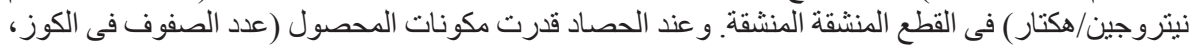

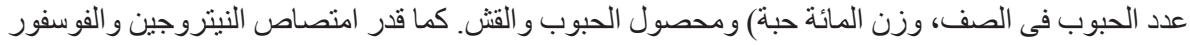

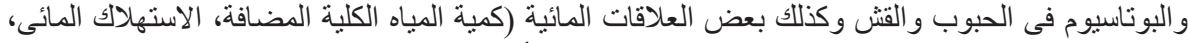

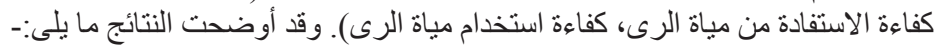

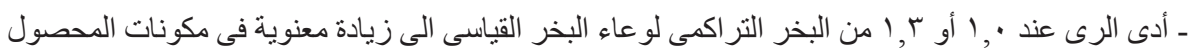

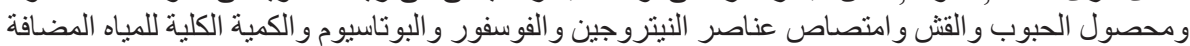

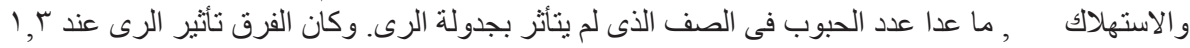

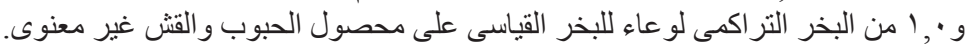

ـ أدى الرى عند ·, ا من البخر التراكمى لو عاء البخر القياسى الى أعلى قيم لكفاءة الاستهلاك و استخدام مياة

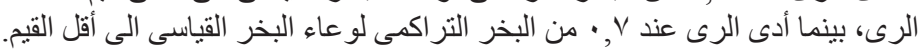

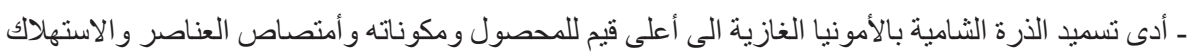

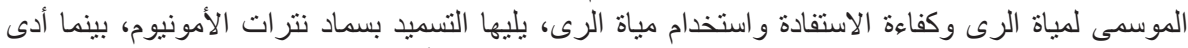

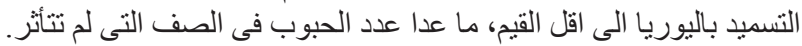

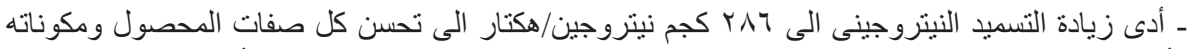
و أمتصاص العناصر والعلاقات المائية ما عدا كمية المياة الكلية المضافة التى لم تثأثر بمستويات التسميد النيتروجينى.

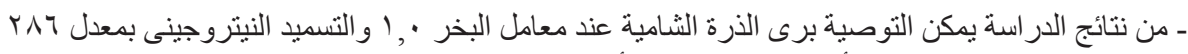

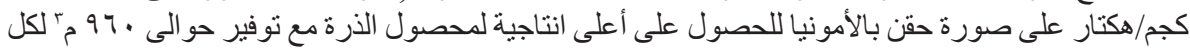

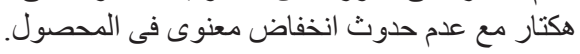

